\title{
Adsorption of cadmium and copper onto natural clay: isotherm, kinetic and thermodynamic studies
}

\author{
El Ass K.* \\ Laboratoire de métrologie environnementale, Ecole Supérieure des Mines de Rabat (ENSMR), BP: 753 Agdal-Rabat, Morocco \\ Received: 17/05/2017, Accepted: 31/01/2018, Available online: 03/04/2018 \\ *to whom all correspondence should be addressed: e-mail: khelass@gmail.com
}

\begin{abstract}
Clay of the Middle Atlas Mountains region, Morocco, was used to investigate the removal of heavy metals ions (Cadmium and Copper) from aqueous solutions with respect to several experimental conditions including $\mathrm{pH}$, contact time, initial solute concentrations, temperature and ionic strength. Kinetic study revealed that metal ions uptake was fast with $90 \%$ or more of the adsorption occurring within first 30 min of contact time. Adsorption rate increased with the increasing initial metal ions concentrations and the sorption rate was well fitted by the pseudo-second-order rate model. The data according to mass transfer and intraparticle diffusion models confirmed diffusion of solutes inside the clay particles as the ratecontrolling step and more important for the adsorption rate than the external mass transfer.
\end{abstract}

The suitability of the adsorbent was tested by fitting the adsorption data with Langmuir and Freundlich isotherm models. Equilibrium and kinetic adsorption data showed that clay displays a high selectivity with an affinity order of $\mathrm{Cd}>\mathrm{Cu}$. Thermodynamic parameters including the Gibbs free energy $(\Delta G)$, enthalpy $(\Delta H)$, and entropy $(\Delta S)$ changes indicated that the present adsorption process was feasible and endothermic in the temperature range of $25-45^{\circ} \mathrm{C}$.

Keywords: Adsorption, Moroccan clay, heavy metals, kinetics, isotherm.

\section{Introduction}

Heavy metal has become a public health concern because of their tendency to accumulate in living organisms, and by that find their way into the human body causing various diseases and disorders (Al-Degs et al., 2006, Inghui and Caoc, 2009). These metals enter the environment due to various industrial procedures including melting, extraction and purification. Presence of heavy metals and their compounds, even in small amounts, in industrial wastewater is very dangerous and must be removed.

Several methods have been applied over the years on the elimination of these metal ions. The usual methods can be ordered as chemical precipitation, ion-exchange, solvent extraction, phytoextraction, ultrafiltration, reverse osmosis, electro-dialysis, coagulation and adsorption ( $\mathrm{Fu}$ and Wang, 2011). Of all the various water-treatment techniques, adsorption is undoubtedly the most important of the physicochemical processes responsible for the uptake of inorganic and organic substances in the aqueous environment. It has been found to be superior to other techniques for wastewater treatment in terms of initial cost, flexibility and simplicity of design, ease of operation and insensitivity to toxic pollutants. Factors such as $\mathrm{pH}$, nature and concentration of substrate and adsorbing ion, ionic strength, and the presence of competing and complex ions affect the extent of adsorption.

The most commonly used adsorbent in industrial wastewater treatment systems is activated carbon because of their high specific surface area, microporous characteristic, and the chemical nature of their surfaces. However, they are expensive, and their regeneration cost is also high. So, there is a dire need for low-cost and readily available materials for the removal of toxic pollutants from water (Crini, 2006).

Natural clays as the adsorbent have received much attention on organic and inorganic pollutants sorption from contaminated water. The use of these materials is becoming popular due to their low-cost, abundant availability, non-toxicity and potential for ion exchange. A number of clay materials: bentonite (Bereket et al., 1997), kaolinite (Jiang et al., 2010), illite (Echeverria et al., 2005), sepiolite (Lazarević et al., 2007), perlite (Alkan and Doagan, 2001), montmorillonite (ljagbemi et al., 2009) and pyrophyllite (Gupta et al., 2009) have been investigated for removal of pollutants. These clay minerals are of interest according to their variety of structural and surface properties, high chemical stability, high specific surface area and high sorption capacity.

Adsorption mechanism at clay surfaces is strictly related to the dual nature of the surface charge, both of permanent and variable nature. A number of mechanisms have been supposed to be active in the sorption of metal ions by these sorbents. Some of these mechanisms are chemisorption, physical adsorption and micro-precipitation which involve (i) an ion exchange reaction at permanent-charge sites and, (ii) formation of complexes with surface hydroxyl groups at edge-sites (Kraepiel et al., 1999, Bradbury and Bayens, 1999). The adsorption capacity of clay minerals can be 
enhanced by replacing the natural exchangeable cations with organic molecules forming the so called "organoclays" (Stathi et al., 2007).

In this work, we attempt to investigate the potential of Moroccan clay, called locally Ghassoul, as an adsorbent. This mineral clay comes from the only deposit in the world, located at the Middle Atlas, Morocco. For several centuries, Ghassoul clay has been used in natural cosmetic products (soap, shampoo, skin conditioner). Currently, it is marketed for its detergent and grease-removing properties. The geochemical characterization and the origin of the Ghassoul clay formation were studied by Chahi et al., (1997, 1999) and Benhammou et al., (2009). The mineralogical composition of Ghassoul clay shows that the raw Ghassoul clay consists mainly of an Mg-rich trioctahedral smectite, stevensite, together with quartz and dolomite.

The empirical chemical formula of raw stevensite is $\mathrm{Si}_{3.78} \mathrm{Al}_{0.22} \mathrm{Mg}_{2.9} \mathrm{Fe}_{0.09} \mathrm{Na}_{0.08} \mathrm{~K}_{0.08} \mathrm{O}_{10}(\mathrm{OH})_{2 .} \mathrm{H}_{2} \mathrm{O}$ (Chahi et al., 1999, Benhammou et al., 2009). At pH 2-12, Ghassoul particles are formed of negatively charged layers responsible via Coulombic attractions of the strong retention of cationic pollutants (Bouna et al., 2010).

This Moroccan clay has been the subject of several recent studies in order to develop new industrial applications. Bejjaoui et al. (2010) were interested in the development of cordierite ceramics by mixing andalusite and Ghassoul clay. El Ass et al., $(2010,2011)$ studied the use of this mineral clay for removal of cationic dyes from aqueous solution.

The main objective of the present study was to evaluate the applicability of Ghassoul clay in removal heavy metals ions (Cadmium and Copper) from aqueous solutions by batch adsorption process. Therefore, the effects of $\mathrm{pH}$, contact time, initial metal concentration, ionic strength, and temperature were investigated. Equilibrium and kinetic analysis were conducted to determine the parameters controlling the rate of adsorption and to find out the possibility of using this material as low-cost adsorbent for metal ions removal.

\section{Materials and methods}

\subsection{Materials}

Ghassoul clay comes from the East side of the Middle Atlas Mountains, approximately $200 \mathrm{~km}$ away from Fes. Ghassoul clay was treated before using in the experiments as follows: a distilled water suspension of the clay was dispersed for approximately $4 \mathrm{~h}$ and then cleaned several times with de-ionized water. The fine fraction was collected by repeated dispersion, sedimentation and siphoning techniques (El Ass et al., 2010). The solid sample was parched at $70{ }^{\circ} \mathrm{C}$ for $24 \mathrm{~h}$ and ground then sieved to pass $140 \mu \mathrm{m}$ mesh (140 $\mu \mathrm{m}$ mesh was proved an appropriate size in the pre-experiment) before being used as adsorbent.

The reagents used to prepare solutions of metal ions were all extra pure analytical grades. The stock solutions of the metals of $1000 \mathrm{mg} \mathrm{L}^{-1}$ were prepared by dissolving weighed quantities of nitrate salts $\left(\mathrm{Cd}\left(\mathrm{NO}_{3}\right)_{2}\right.$ and $\left.\mathrm{Cu}\left(\mathrm{NO}_{3}\right)_{2}\right)$ in twicedistilled water. The $\mathrm{pH}$ of solution was adjusted by using $0.1 \mathrm{M}(\mathrm{NaOH})$ and/or $0.1 \mathrm{M}\left(\mathrm{HNO}_{3}\right)$. The concentration of Cadmium and Copper were determined using an atom adsorption spectrophotometer (AA300, Perkin Elmer, USA).

\subsection{Methods}

Batch adsorption experiments were performed on a rotary shaker at $110 \mathrm{rpm}$ using $125 \mathrm{~mL}$ capped polyethylene bottles containing $100 \mathrm{~mL}$ of solutions and $0.1 \mathrm{~g}$ of adsorbent. Experiments were performed at room temperature $\left(\sim 25^{\circ} \mathrm{C}\right)$ and at solutions $\mathrm{pH}$, except those in which the effects of temperature and $\mathrm{pH}$ were investigated. An adsorbent dose of $1 \mathrm{~g} / \mathrm{L}$ was kept constant for all of the adsorption experiments. The preliminary experiment revealed that about $60 \mathrm{~min}$ was required for the adsorption process to reach equilibrium. Therefore, a contact period of 90 min was finally selected for all of the equilibrium tests. The solution and solid phase were separated by centrifugation at $4000 \mathrm{rpm}$ for $10 \mathrm{~min}$ and the supernatant was kept for analyses. Various conditions, including the contact time, the $\mathrm{pH}$, the initial solute concentration and the ionic strength were tested.

The metal ion concentrations, retained in the adsorbent phase $\left(q_{e}, \mathrm{mg} \mathrm{g}^{-1}\right)$, were calculated by using the following equation:

$$
q_{e}=\frac{C_{0}-C_{e}}{m} \cdot v
$$

where $C_{0}\left(\mathrm{mg} \mathrm{L}^{-1}\right)$ is the initial concentration, $C_{e}\left(\mathrm{mg} \mathrm{L}^{-1}\right)$ is the equilibrium concentration in aqueous solution, $V(L)$ is the volume of solution, $m(\mathrm{~g})$ is the mass of the Ghassoul clay and $q_{e}\left(\mathrm{mg} \mathrm{g}^{-1}\right)$ is the calculated adsorption amount onto Ghassoul clay.

Blanks containing no pollutants were used for each series of experiments. Each experimental point was an average of three independent adsorption tests.

\section{Results and discussions}

\subsection{Characterization of the Ghassoul clay}

Mineralogical identification of adsorbent was performed by a Siemens $\mathrm{D} 5000$ X-ray diffraction instrument with filtered Cu Ka radiation $(n=1.5418 \AA$ ).

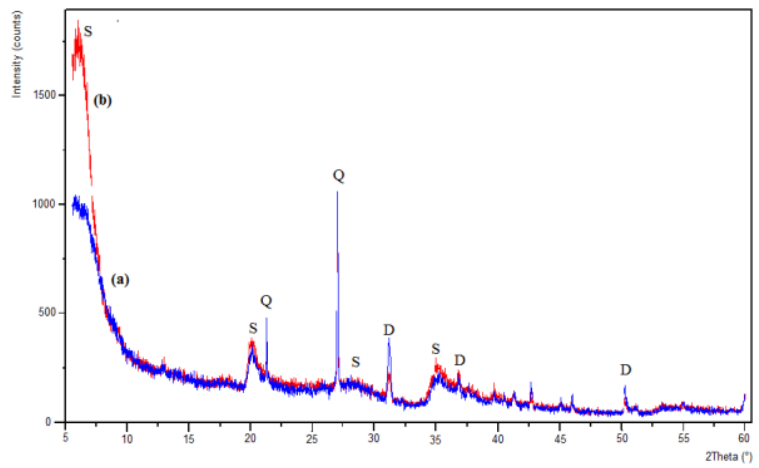

Figure 1. XRD diagrams of (a) the raw sample and (b) the separatedfine fraction of Ghassoul clay 
The XRD pattern of raw Ghassoul clay (Fig. 1a) showed that the dominant phase is the stevensite with the presence of quartz and dolomite. The XRD pattern of the fine fraction (Fig. 1b) shows (i) an increase in the abundance of stevensite, indicating that the clay fraction of the Ghassoul clay consists mainly by phyllosilicates, (ii) significant decrease in the abundance of quartz and disappearance of dolomite.

The chemical composition of the raw Ghassoul clay and its fine mineral fraction are presented in Table 1 . These results show that the fine fractions are principally made up of $\mathrm{SiO}_{2}$ (58.16 wt.\%) and $\mathrm{MgO}$ (27.44 wt.\%). $\mathrm{Al}_{2} \mathrm{O}_{3}$ is notably concentrated in the fine clay mineral fraction (4.48 wt.\%). The large amount of $\mathrm{CaO}$ (12.13 wt.\%) measured in the raw clay may be ascribed partly to the dolomite recognized in
XRD patterns, but particularly to gypsum. Indeed, gypsum has been reported to be present in the Ghassoul clay deposit by (Benhammou, 2005).

The surface area of fine mineral fraction, measured by the $\mathrm{N}_{2}$-BET method, is $137 \mathrm{~m}^{2} / \mathrm{g}$. This high value, compared with other clays, reveals the existence of a high porosity responsible for the strong capacity of this material to fix some cations. The $\mathrm{pH}$ of zero-point charge $\mathrm{pH}_{\mathrm{zPC}}=2.1$, the same result was found by Bouna et al., (2010) and Benhammou, et al., (2005). The cation exchange capacity is $79 \mathrm{meq} / 100 \mathrm{~g}$, relatively large, compared to the values for natural stevensite, reported by Faust and Murata, (1953) and Takahashi et al., (1997) to be 37.6 and $41 \mathrm{meq} / \mathrm{l00} \mathrm{g}$, respectively. It is noted that the prevalent exchangeable element is $\mathrm{Mg}^{2+}$, which presents $73.11 \%$ of the CEC.

Table 1. Chemical composition of the raw Ghassoul clay and its fine mineral fraction

\begin{tabular}{ccc}
\hline Sample Oxides & Raw Clay (wt.\%) & Fine Fraction (wt.\%) \\
\hline $\mathrm{SiO}_{2}$ & 53.31 & 58.16 \\
\hline $\mathrm{Al}_{2} \mathrm{O}_{3}$ & 2.87 & 4.48 \\
\hline $\mathrm{Fe}_{2} \mathrm{O}_{3}$ & 1.44 & 1.92 \\
\hline $\mathrm{MgO}_{\mathrm{CaO}}$ & 24.64 & 27.44 \\
\hline $\mathrm{Na}_{2} \mathrm{O}$ & 12.13 & 1.88 \\
\hline $\mathrm{K}_{2} \mathrm{O}$ & 1.12 & 0.17 \\
\hline $\mathrm{Total}$ & 0.85 & 1.05 \\
\hline
\end{tabular}

\subsection{The effect of solution $\mathrm{pH}$}

$\mathrm{pH}$ is one of the most important factors which control the adsorption capacity of pollutants on clay surfaces. Change of $\mathrm{pH}$ affects the adsorptive process through dissociation of functional groups on the adsorbent surface-active sites.

The effect of solution $\mathrm{pH}$ on the equilibrium up-take capacity of Ghassoul clay was studied at initial concentrations of $400 \mathrm{mg} \mathrm{L}^{-1}$ for $\mathrm{Cd}(\mathrm{II})$ and $200 \mathrm{mg} \mathrm{L}^{-1}$ for $\mathrm{Cu}$ (II) between $\mathrm{pH}$ values of 2 and 9. As shown in Fig.2, the amount of adsorbed metals was found to increase with an increase in $\mathrm{pH}$, which can be explained by the electrostatic interactions of cationic metal ions with the negatively charged surface. At the $\mathrm{pH}$ interval of the experiments, the surface of Ghassoul clay is predominantly negative, due to silanol $\left(\mathrm{SiOH}^{-}\right)$and aluminol $\left(\mathrm{AlOH}^{-}\right)$groups (Stumm, 1997), which is in accordance with the value of the zeta potential $\left(\mathrm{pH}_{\mathrm{zpc}}\right.$ 2.1) for this mineral (Bouna et al., 2010). Similar results were observed using natural kaolinite clay for the adsorption of $\mathrm{Pb}(\mathrm{II}), \mathrm{Cd}(\mathrm{II}), \mathrm{Ni}(\mathrm{II})$ and $\mathrm{Cu}(\mathrm{II})$ (Jiang et al., 2010) and for adsorption of $\mathrm{Pb}$ (II) and $\mathrm{Cd}(\mathrm{II})$ ions on tripolyphosphate-modified kaolinite clay (Adebowale et al., 2008).

At very low $\mathrm{pH}$, the number of $\mathrm{H}_{3} \mathrm{O}^{+}$ions exceeds that of metal ions by several times and the metal ions can hardly compete with $\mathrm{H}_{3} \mathrm{O}^{+}$ions for the binding sites on the clay adsorbents and thus, electrostatic repulsion occurred between the metal ions $\left(\mathrm{M}^{2+}\right)$ and the edge groups with positive charge $\left(\mathrm{SiOH}_{2}^{+}\right)$on the surface as follows:

$\mathrm{SiOH}+\mathrm{H}^{+} \rightarrow \mathrm{SiOH}_{2}^{+}+\mathrm{OH}^{-}$

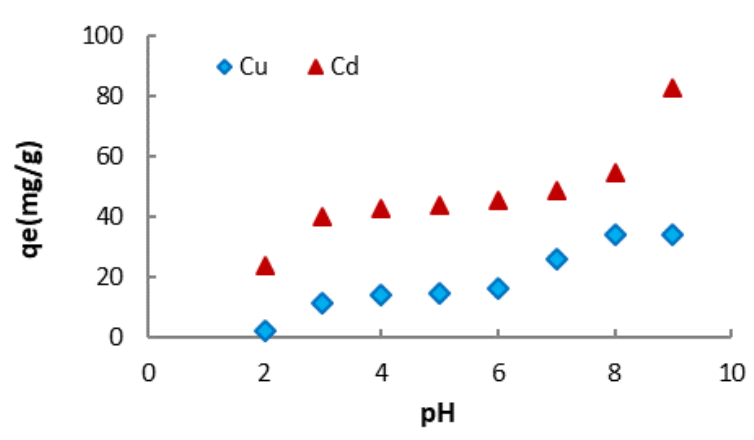

Figure 2. The effect of initial solution $\mathrm{pH}$ on the removal of $\mathrm{Cd}(\mathrm{II})$ and $\mathrm{Cu}(\mathrm{II})$ onto Ghassoul clay

With an increase in $\mathrm{pH}$, the concentration of $\mathrm{H}_{3} \mathrm{O}^{+}$ions decreases and some of the sites become available to the metal ions. As the acidity decreases, more and more $\mathrm{H}_{3} \mathrm{O}^{+}$ ions on the clay surface are replaced by metal ions and metal species such as $\mathrm{Cd}^{2+}, \mathrm{Cd}(\mathrm{OH})^{+}$, and $\mathrm{Cd}(\mathrm{OH})_{2}$ (Lai et al., 2002) and $\mathrm{Cu}^{2+}, \mathrm{Cu}(\mathrm{OH})^{+}$, and $\mathrm{Cu}_{2}(\mathrm{OH})_{2}{ }^{2+}$ (Bosso and Enzweiler, 2002). This happens at lower pH ( 6.0) for $\mathrm{Cu}(\mathrm{II})$ (Nuhoglu and Oguz, 2003), while the adsorption could be safely carried out to $\mathrm{pH}$ ( 9.0) for Cd(II) (Mathialagan and Viraraghavan, 2002). Experiments were not conducted beyond $\mathrm{pH} 6.0$ for $\mathrm{Cd}(\mathrm{II})$ and $\mathrm{Cu}(\mathrm{II})$ to avoid the precipitation of metal ions.

In an alkaline medium, the surface of Ghassoul clay becomes negatively charged and electrostatic repulsion decreases with raising $\mathrm{pH}$ due to reduction of positive charge density on the sorption edges thus resulting in an 
increase metal adsorption. This mechanism can be shown as follows:

$$
\begin{aligned}
& \mathrm{SiOH}+\mathrm{OH}^{-} \Leftrightarrow \mathrm{SiO}^{-}+\mathrm{H}_{2} \mathrm{O} \\
& \mathrm{SiO}+\mathrm{M}^{2+} \Leftrightarrow \mathrm{SiOM}^{2+}
\end{aligned}
$$

A similar theory was proposed by several earlier workers for metal adsorption on different adsorbents (Sari et al., 2007).

\subsection{Effect of ionic strength}

The ionic strength of the solution is one of the factors that control both electrostatic and non-electrostatic interactions between the adsorbate and the adsorbent surface. The influence of ionic strength on the adsorption of $\mathrm{Cd}(\mathrm{II})$ and $\mathrm{Cu}(\mathrm{II})$ ions was investigated using $\mathrm{NaCl}$ and $\mathrm{CaCl}_{2}$ solutions. It was observed that when ionic strength of both electrolyte increased from 0.01 to $0.1 \mathrm{~mol} \mathrm{~L}^{-1}$, the total decrease in percentage removal of $400 \mathrm{mg} \mathrm{L}^{-1} \mathrm{Cd}$ (II) and $200 \mathrm{mg} \mathrm{L}^{-1} \mathrm{Cu}$ (II) was 34.17 and 19.41, respectively, for Ca-electrolyte and 23.87 and 15.33, respectively, for Naelectrolyte. This suggests that with increase in the concentration of chloride anions in metal ion solution, there is a possibility for the formation of uncharged species and negatively charged chloride complexes $\left(\mathrm{MCl}_{2}, \mathrm{MCl}_{3}{ }^{-}\right.$ and $\mathrm{MCl}_{4}{ }^{2-}$ ) that will invariably reduce the adsorption capacity of the adsorbent for positively charged cations. It was also observed that the adsorbents show stronger preference for $\mathrm{Ca}^{2+}$ (a divalent cation) than for $\mathrm{Na}^{+}$(a monovalent cation) with the resultant effect of a further drop in monolayer adsorption capacities of the adsorbents for the metal ions when Ca-electrolytes were used.

Similar results were found by several earlier workers for metals adsorption on different adsorbents (Jiang et al., 2010, Adebowale et al., 2006, Ozdes et al., 2011).

Adebowale et al., (2006) have reported that the presence of electrolyte $\left(\mathrm{NaCl}\right.$ and $\left.\mathrm{CaCl}_{2}\right)$ and their increasing concentration reduced the adsorption capacities of both unmodified and p-modified kaolinite clay for the metal ions. They have demonstrated that Ca-electrolytes had more negative effect on the adsorption capacities of the adsorbents than Na-electrolytes. Ca-electrolytes reduced adsorption capacities of the adsorbents for $\mathrm{Pb}$ and $\mathrm{Cd}$ ions.

The $\mathrm{NaCl}, \mathrm{KCl}, \mathrm{NaNO}_{3}$, and $\mathrm{Na}_{2} \mathrm{HPO}_{4}$ salts were chosen as electrolytes by Ozdes et al., (2011) to investigate the effect of ionic strength on $\mathrm{Pb}$ (II) and $\mathrm{Cd}$ (II) adsorption onto Turkish illitic clay. They have observed that there was a decrease in the adsorption capacities of clay for $\mathrm{Cd}$ (II) and $\mathrm{Pb}$ (II) ions with increasing the concentration of electrolytes. These results can be attributed by these reasons: (i) the competition between cations of the salts and metal ions for the active adsorption sites of clay (ii) the active adsorption sites of the clay may be blocked in the presence of these salts.

\subsection{Adsorption isotherms and equilibrium}

\subsubsection{Effects of initial metal ions concentration}

The effects of initial metal ions concentration on the adsorption process were evaluated by varying initial metal ions concentration in the range of $50-800 \mathrm{mg} \mathrm{L}^{-1}$ for $\mathrm{Cd}$ (II) and in the range of $25-400 \mathrm{mg} \mathrm{L}^{-1}$ for $\mathrm{Cu}(\mathrm{II})$. With increasing metal ions loading, the amount adsorbed per unit mass of clay adsorbents $\left(q_{e}\right)$ increases gradually (Fig. 3 ) while the extent of adsorption (\%) decreases. As calculated from adsorption data, the amount of $\mathrm{Cd}(\mathrm{II})$ and $\mathrm{Cu}(\mathrm{II})$ increased from 11.5 to $73,55 \mathrm{mg} \mathrm{g}^{-1}$ and from 5.93 to $15,19 \mathrm{mg} \mathrm{g}^{-1}$ whereas adsorption percentage decreased from $92 \%$ to $36.77 \%$ and from $94.83 \%$ to $15.75 \%$, respectively.
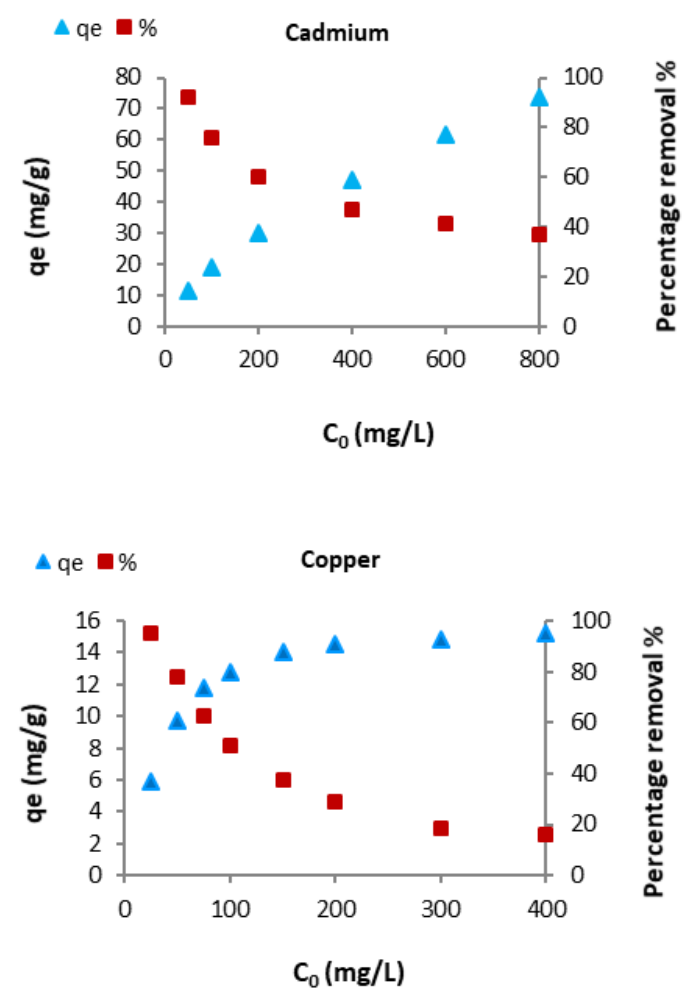

Figure 3. Effect of initial metal concentration on the adsorption of $\mathrm{Cd}(\mathrm{II})$ and $\mathrm{Cu}$ (II) onto Ghassoul clay

Similar observations for metal ions uptake on different adsorbents have been reported earlier by Ozdes et al., (2011) and Sdiri et al., (2011). It appears that, at low Cd(II) and $\mathrm{Cu}(\mathrm{II})$ ions concentration, a large number adsorption sites are available to the metal ions and the adsorption is independent of the initial concentration. The situation changes with increasing metal ions concentration and the competition for adsorption sites become strong. Under such circumstances, the unit mass of the adsorbent could take up many more metal ions but the overall percentage adsorption shows a decreasing trend (Bhattacharyya and Gupta, 2011). The adsorption equilibrium is established when the amount of metal ions fixed at the interface solid solution is in dynamic balance with that on surface.

\subsubsection{Adsorption isotherms}

Generally, adsorption isotherms provide vital information in optimizing the use of adsorbents. The two most commonly employed models are the Langmuir and Freundlich isotherms, which have shown to be suitable for 
describing short-term and mono-component adsorption of metal ions by different materials.

The physical and mathematical explanations of the adsorption and interpretation of the monolayer adsorption isotherms measured on homogeneous surfaces was started by Langmuir in 1916. This theory is based on the dynamic character of adsorption. At equilibrium, the numbers of adsorbed and desorbed molecules in unit time on unit surface are equal. Langmuir's theory does not take the lateral interactions and horizontal mobility of the adsorbed molecules into account (Langmuir, 1918). The Langmuir equation can be written in the form:

$$
q_{e}=q_{m}\left[\frac{K_{L} \cdot C_{e}}{1+K_{L} \cdot C_{e}}\right]
$$

where $\mathrm{Ce}$ is the equilibrium concentration of the solution (mol L-1), qe the amount of adsorbed per unit mass of adsorbent $\left(\mathrm{mol} \mathrm{g}^{-1}\right)$, and $\mathrm{qm}$ is the monolayer capacity (mol $\left.\mathrm{g}^{-1}\right) ; K_{L}$ is the constant related to the energy of adsorption $\left(\mathrm{L} \mathrm{mol}^{-1}\right)$. The steepness of the isotherm is determined by $K_{L} . K_{L}$ can be considered to be a measure of the affinity of the adsorbate for the surface. The value of $q m$ is the upper limit for qe and represents the maximum adsorption of adsorbate determined by the number of reactive surface adsorption sites. The parameters $q m$ and $K$ can be calculated from adsorption data by converting the Langmuir equation into the linear form (Langmuir et al., 1918):

$$
\frac{c_{e}}{q_{e}}=\frac{c_{e}}{q_{m}}+\frac{1}{\left(q_{m} \cdot K_{L}\right)}
$$

The Freundlich isotherm is applicable to both monolayer and multilayer adsorption and is based on the assumption that the adsorbate adsorbs onto the heterogeneous surface of an adsorbent (Yang, 1998).

The Freundlich equation has the form:

$$
\mathrm{q}_{\mathrm{e}}=\mathrm{K}_{\mathrm{F}} \cdot \mathrm{C}_{\mathrm{e}}^{1 / \mathrm{n}}
$$

The linear form of Freundlich equation obtained, by the logarithmic linearization of the Freundlich equation, is expressed as:

$$
\log q_{e}=\log K_{F}+\left(\frac{1}{n}\right) \log C_{e}
$$

where $K_{F}\left(\mathrm{mg} \mathrm{g}^{-1}\right)$ and $n$ are Freundlich constants incorporating all factors affecting the adsorption process such as adsorption capacity and intensity of adsorption. These constants are determined from the intercept and slope of linear plot of $\log q_{e}$ versus $\log C_{e}$, respectively.

The analysis of the isotherm data by fitting them to different isotherm models is an important step to find the suitable model that can be used for design purposes.

Fig. 4 show the Langmuir $\left(1 / q_{e}\right.$ versus $\left.1 / C_{e}\right)$ and Freundlich (In $q_{e}$ versus $\ln C_{e}$ ) plots, respectively, for the removal of the
$\mathrm{Cd}(\mathrm{II})$ and $\mathrm{Cu}$ (II) onto Ghassoul clay. This indicated that the adsorption sites were non-uniform and nonspecific in nature. It was in conformity with the existence of different types of possible adsorption sites on clay surface with considerable difference in energy if the site was on an edge or was located in a defect position (Jiang et al., 2010).
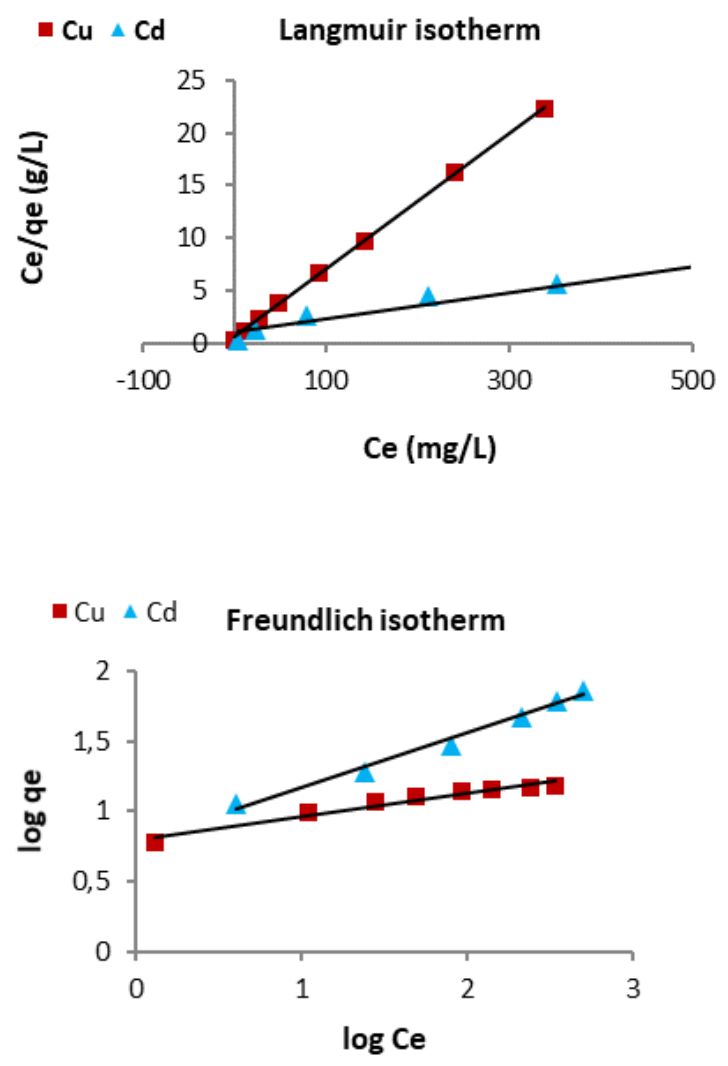

Figure 4. Adsorption isotherm models of $\mathrm{Cd}(\mathrm{II})$ and $\mathrm{Cu}$ (II) adsorption onto Ghassoul clay

The calculated values of the constants in Langmuir and Freundlich equations and the regression correlation coefficients $\left(R^{2}\right)$ are given in Table 2 . The Freundlich coefficient, $n$ obtained in the present study for both metal ions are greater than unity, $n$ values between 2.5 and 6 indicate that the adsorption of $\mathrm{Cd}$ (II) and $\mathrm{Cu}$ (II) onto Ghassoul clay under studied conditions was favorable (Unuabonah et al., 2008).

According to the Langmuir isotherm model, the maximum monolayer adsorption capacity of Ghassoul clay for $\mathrm{Cd}$ (II) was found to be higher than for $\mathrm{CU}(\mathrm{II})$ ions indicating that Ghassoul clay showed stronger preference for Cd(II) than for $\mathrm{Cu}(\mathrm{II})$. The monolayer adsorption capacity was found as 86.34 and $15.41 \mathrm{mg} \mathrm{g}^{-1}$ for $\mathrm{Cd}$ (II) and $\mathrm{Cu}(\mathrm{II})$ respectively. Jiang et al., (2010) and Lv et al., (2005) have reported the same affinity order: $\mathrm{Cd}(\mathrm{II})>\mathrm{Cu}(\mathrm{II})$. 
Table 2. Langmuir and Freundlich isotherm parameters for the adsorption of $\mathrm{Cd}(\mathrm{II})$ and $\mathrm{Cu}(\mathrm{II})$ onto Ghassoul clay.

\begin{tabular}{lccccccc}
\hline & \multicolumn{3}{c}{ Langmuir constants } & \multicolumn{4}{c}{ Freundlich constants } \\
& $\mathbf{q}_{\mathbf{m}(\exp )}\left(\mathrm{mg} \mathrm{g}^{-1}\right)$ & $\mathbf{q}_{\mathbf{m}(\text { cal) }}\left(\mathrm{mg} \mathrm{g}^{-1}\right)$ & $\mathbf{K}_{\mathrm{L}}\left(\mathrm{L} \mathrm{mg}^{-1}\right)$ & $\mathbf{R}^{\mathbf{2}}$ & $\mathbf{n}$ & $\mathbf{K}_{\mathrm{F}}\left(\mathrm{mg} \mathrm{g}^{-1}\right)$ & $\mathbf{R}^{\mathbf{2}}$ \\
$\mathrm{Cd}(\mathrm{II})$ & 73.55 & 86.34 & 0.011 & 93.73 & 2.55 & 5.86 & 98.46 \\
$\mathrm{Cu}(\mathrm{II})$ & 15.19 & 15.41 & 0.136 & 99.94 & 5.90 & 11.07 & 95.26 \\
\hline
\end{tabular}

\subsection{Adsorption kinetics}

\subsubsection{Effect of contact time and initial concentration}

The effect of contact time on the sorption of metal ions was analyzed kinetically over a range of 5-180 min. Adsorption was carried out at initial concentrations range of 200-600 $\mathrm{mg} \mathrm{L}^{-1}$ and 100-400 $\mathrm{mg} \mathrm{L}^{-1}$ for $\mathrm{Cd}(\mathrm{II})$ and $\mathrm{Cu}(\mathrm{II})$, respectively. As can be seen in Fig. 5, the equilibrium adsorption was very fast and maximum uptake was reached within $30 \mathrm{~min}$, thereafter, the amount of adsorption remained almost constant. Increasing concentration gradient, acts as increasing driving force, and in turn leads to an increasing equilibrium sorption until sorbent saturation is achieved. The same results were reported by other investigators (Sdiri et al., 2011, Potgieter et al., 2006), who found that the equilibrium time clays was short.

\subsubsection{Kinetics studies}

The experimental data were fitted through three kinetics models including pseudo-first order, pseudo-second order kinetic models and intraparticle diffusion models.

The pseudo first-order equation (Lagergren's equation) describes adsorption in solid-liquid systems based on the sorption capacity of solids (Lagergren, 1898, Ho, 2006) The Lagergren's first-order reaction model is expressed as follows:

$$
\log \left(q_{e}-q_{t}\right)=\log q_{e}-\frac{k_{1}}{2.303} t
$$

where $q_{t}$ is the amount of adsorption at time $t\left(\mathrm{mg} \mathrm{g}^{-1}\right) ; k_{1}$ is the rate constant of the equation $\left(\mathrm{min}^{-1}\right)$ and $q_{e}$ is the amount of adsorption equilibrium $\left(\mathrm{mg} \mathrm{g}^{-1}\right)$. The adsorption rate constant $k_{1}$, can be determined experimentally by plotting of $\ln \left(q_{e}-q_{t}\right)$ versus $t$.

The pseudo-second-order model is based on the assumption of chemisorption of the adsorbate on the adsorbent. This model as described by Ho, (2006) is expressed as:

$$
\frac{t}{q_{t}}=\frac{1}{k_{2} q_{e}^{2}}+\frac{t}{q_{e}}
$$

where $k_{2}\left(\mathrm{~g} \mathrm{mg}^{-1} \mathrm{~min}^{-1}\right)$ is the rate constant of the secondorder equation; $q_{e}$ and $q_{t}$ are the amount of adsorption (mg $\mathrm{g}^{-1}$ ) at equilibrium and at time $t$, respectively.

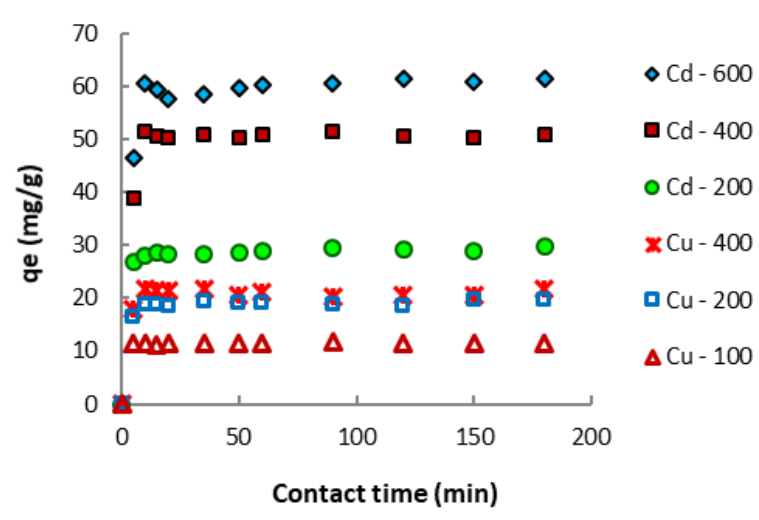

Figure 5. Effect of contact time on the adsorption of various concentrations of $\mathrm{Cd}(\mathrm{II})$ and $\mathrm{Cu}$ (II)

The form of the intraparticle diffusion model described by Weber and Morris, (1963) is:

$$
q_{t}=k_{\text {id }} t / \frac{1}{2}+C
$$

where $\mathrm{qt}_{\mathrm{t}}\left(\mathrm{mg} \mathrm{L}^{-1}\right)$ is the amount of adsorption time $\mathrm{t}(\mathrm{min})$, $k_{\text {id }}\left(\mathrm{mg} \mathrm{g}^{-1} \mathrm{~min}^{-1 / 2}\right.$ ) is the rate constant of intraparticle diffusion and $\mathrm{C}\left(\mathrm{mg} \mathrm{g}^{-1}\right)$ is the intercept, which represents the thickness of the boundary layer (Furusawa and Smith, 1974).

By testing the plots of $\log \left(q_{e}-q_{t}\right)$ versus $t$ and $\left(t / q_{t}\right)$ versus $t$ (Fig. 6), for the adsorption of $\mathrm{Cd}(\mathrm{II})$ and $\mathrm{Cu}(\mathrm{II})$ onto Ghassoul clay at various concentrations, the rate constants $k_{1}$ and $k_{2}$, and correlation coefficients can be calculated, the results are shown in Table 3.

As seen from Table 3, the correlation coefficients $\left(R^{2}\right)$, for the pseudo second-order kinetic model fits, are much higher $(>0,99)$ than those derived from pseudo first-order model fits. Also, the $q_{e}$ calculated values fit the experimental data. This suggests that the pseudo-secondorder adsorption mechanism is predominant and that the overall rate of the $\mathrm{Cd}(\mathrm{II})$ and $\mathrm{Cu}(\mathrm{II})$ adsorption process appeared to be controlled by the chemical process (Chen and Wang, 2007). Similar results were found by Sdiri et al., (2011) who studied the adsorptive capacity of montmorillonitic and calcareous clays on the removal of several heavy metals and by Jiang et al., (2010) who studied the removal of $\mathrm{Pb}(\mathrm{II}), \mathrm{Cd}(\mathrm{II}), \mathrm{Ni}(\mathrm{II})$ and $\mathrm{Cu}(\mathrm{II})$ ions onto natural clay. 

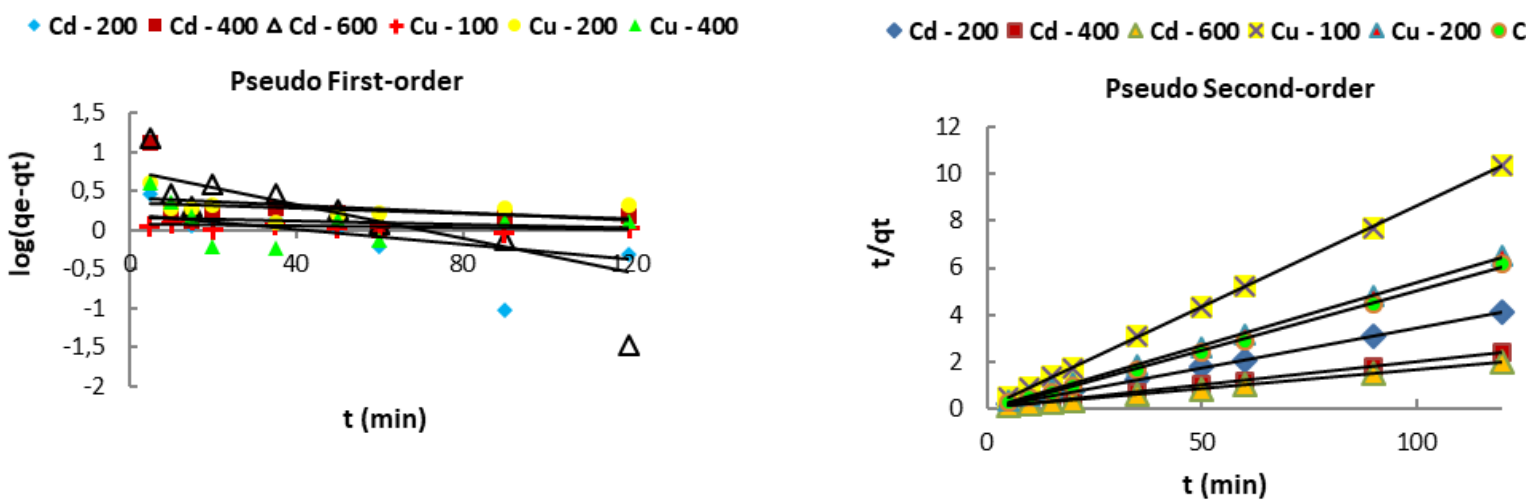

Figure 6. Pseudo First-order and Pseudo second-order plots for the adsorption of Cd(II) and C(II) at various concentrations

Table 3. Kinetics parameters for the adsorption of $\mathrm{Cd}(\mathrm{II})$ and $\mathrm{Cu}(\mathrm{II})$ onto Ghassoul clay at various concentrations.

\begin{tabular}{|c|c|c|c|c|c|c|}
\hline & \multicolumn{3}{|c|}{$\mathrm{Cd}\left(\mathrm{mg} \mathrm{L}^{-1}\right)$} & \multicolumn{3}{|c|}{$\mathrm{Cu}\left(\mathrm{mg} \mathrm{L}^{-1}\right)$} \\
\hline & 200 & 400 & 600 & 100 & 200 & 400 \\
\hline$q_{e(e x p)}\left(m g^{-1}\right)$ & 29,0 & 50,9 & 61,3 & 11.6 & 19.5 & 21.7 \\
\hline \multicolumn{7}{|c|}{ First-order kinetics model } \\
\hline $\mathbf{k}_{1} * 10^{2}\left(\mathrm{~min}^{-1}\right)$ & $-1,19$ & $-0,55$ & $-2,46$ & -0.11 & -0.41 & 0.27 \\
\hline $\mathbf{q}_{\mathrm{e}(\mathrm{cal})}\left(\mathrm{mg} \mathrm{g}^{-1}\right)$ & 1,87 & 2,54 & 5,63 & 1.17 & 2.27 & 1.60 \\
\hline $\mathbf{R}^{2}$ & 39,29 & 14,47 & 59,49 & 27.6 & 28.5 & 29.0 \\
\hline \multicolumn{7}{|c|}{ Pseudo-second-order model } \\
\hline $\mathbf{q}_{\mathrm{e}(\mathrm{cal})}\left(\mathrm{mg} \mathrm{g}^{-1}\right)$ & 29,4 & 50,7 & 61,7 & 11.6 & 19.4 & 20.9 \\
\hline $\mathbf{k}_{\mathbf{2}} * 10^{2}\left(\mathrm{~g} \mathrm{mg}^{-1} \mathrm{~min}^{-1}\right)$ & 3,66 & 6,16 & 1,33 & 39.1 & 4.02 & 8.69 \\
\hline $\mathbf{R}^{2}$ & 99,9 & 99,9 & 99,9 & 100 & 99.8 & 99.6 \\
\hline
\end{tabular}

According to Weber and Morris model, the plots of $q_{t}$ versus $t^{1 / 2}$ (Fig. 7), for the adsorption of Cd(II) and C(II) onto Ghassoul clay at various concentrations, show that intraparticle diffusion occurred in two stages for both the metal ions.
The first phase is attributed to the diffusion of metal ions through the solution to the external surface and the second phase indicates the intraparticle diffusion of metal ions into the pores of Ghassoul clay.

Table 4. Kinetics parameters for the adsorption of $\mathrm{Cd}(\mathrm{II})$ and $\mathrm{Cu}(\mathrm{II})$ onto Ghassoul clay at various concentrations.

\begin{tabular}{lcccccc}
\hline & \multicolumn{3}{c}{$\mathbf{C d}\left(\mathbf{m g ~ L}^{-\mathbf{1}}\right)$} & \multicolumn{3}{c}{$\mathbf{C u}\left(\mathbf{m g ~ L}^{-\mathbf{1}}\right)$} \\
\hline $\mathbf{K}_{\mathbf{1 d}}\left(\mathrm{mg} \mathrm{g}^{-1} \mathrm{~min}^{-1 / 2}\right)$ & $\mathbf{2 0 0}$ & $\mathbf{4 0 0}$ & $\mathbf{6 0 0}$ & $\mathbf{1 0 0}$ & $\mathbf{2 0 0}$ & $\mathbf{4 0 0}$ \\
\hline $\mathbf{C}_{\mathbf{1}}$ & 2,51 & 13,55 & 15,25 & 1,21 & 2,35 & 3,09 \\
\hline $\mathbf{R}^{\mathbf{2}}$ & 10,09 & 8,47 & 12,28 & 7,54 & 11,3 & 11,02 \\
\hline $\mathbf{K}_{\mathbf{2 d}}\left(\mathrm{mg} \mathrm{g}^{-1} \mathrm{~min}^{-1 / 2}\right)$ & 1 & 1 & 1 & 1 & 1 & 1 \\
\hline $\mathbf{C}_{\mathbf{2}}$ & 0,19 & 0,03 & 0,42 & 0,034 & 0,02 & 0,161 \\
\hline $\mathbf{R}^{\mathbf{2}}$ & 17,28 & 50,37 & 56,55 & 11,27 & 18,9 & 22,12 \\
\hline
\end{tabular}

For the first sharper portion, i.e. from 0 to $10 \mathrm{~min}$, its rates, $k_{1 d}\left(2.51-15.25 \mathrm{mg} \mathrm{g}^{-1} \mathrm{~min}^{-1 / 2}\right.$ for Cd(II) and 1.209-3.097 mg $\mathrm{g}^{-1} \mathrm{~min}^{-1 / 2}$ for $\left.\mathrm{Cu}(\mathrm{II})\right)$, shows that the adsorption process is very fast. The second portion with $k_{2 d}\left(0.19-0.42 \mathrm{mg} \mathrm{g}^{-1}\right.$ $\mathrm{min}^{-1 / 2}$ for $\mathrm{Cd}(\mathrm{II})$ and $0.034-0.161 \mathrm{mg} \mathrm{g}^{-1} \mathrm{~min}^{-1 / 2}$ for $\mathrm{Cu}(\mathrm{II})$ ) can be rate controlling. However, the intraparticle diffusion model is not the only rate limiting mechanism since the line did not pass through the origin. From the above analysis, it can be concluded that both film diffusion and intra-particle diffusion were simultaneously operating during the process of the adsorption of $\mathrm{Cd}(\mathrm{II})$ and $\mathrm{Cu}(\mathrm{II})$ onto Ghassoul clay.
The same type results were also given in some works (Sari et al., 2007, Ozdes et al., 2011, Chen et al., 2007).

The intraparticle rate constants for the first phase $\left(k_{1 d}\right)$ and second phase $\left(k_{2 d}\right)$ and $C$ parameters were given in Table 4.

\subsection{Thermodynamic studies}

\subsubsection{Effect of temperature}

The removal efficiency of metal ions was investigated in the temperature range of $25-45^{\circ} \mathrm{C}$ at initial concentrations of 400 and $200 \mathrm{mg} \mathrm{L}^{-1}$ for $\mathrm{Cd}(\mathrm{II})$ and $\mathrm{Cu}(\mathrm{II})$ respectively (Table 5). 
The adsorption efficiency increased from 61.87 to $69.88 \mathrm{mg}$ $\mathrm{g}^{-1}$ for $\mathrm{Cd}$ (II) and from 18.86 to $22.03 \mathrm{mg} \mathrm{g}^{-1}$ for $\mathrm{Cu}(\mathrm{II})$, when the temperature was increased from 25 to $45^{\circ} \mathrm{C}$, indicating that the adsorption process for both metal ions was endothermic in nature. The increase in the adsorption capacity of Ghassoul clay with temperature may be

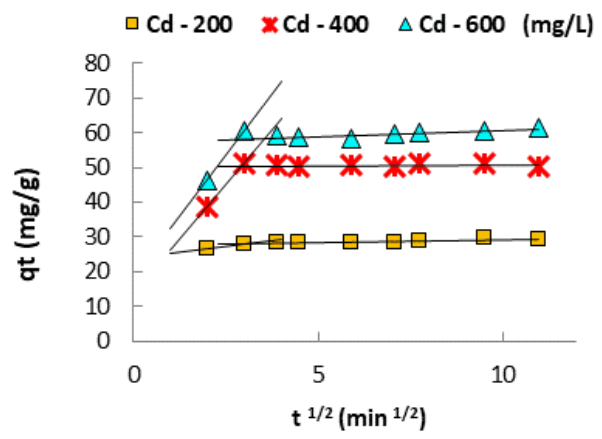

attributed to either increase in number of available active surface sites on the Ghassoul clay surface or increase in the mobility of metal cations (Adebowale et al., 2008). Similar observations have been reported earlier by Bhattacharyya and Gupta, (2011) for removal of Cu(II) by natural and acidactivated clays.

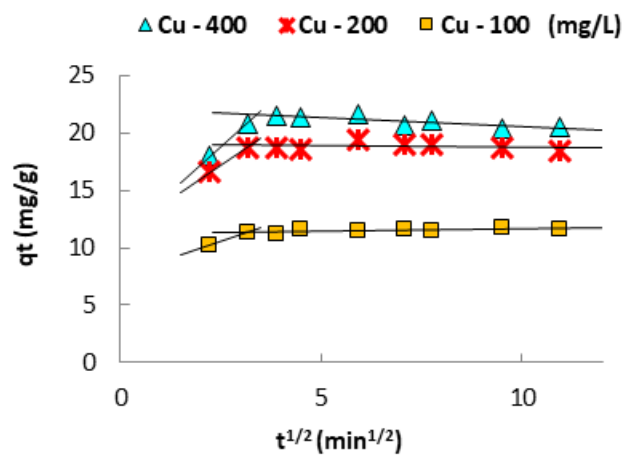

Figure 7. Intra-particle diffusion plots for the adsorption ofCd(II) and C(II) onto Ghassoul clay at various concentrations

Table 5. Adsorptive capability of metal ions onto Ghassoul clay at different temperatures

\begin{tabular}{cccc} 
& \multicolumn{3}{c}{ Temperature $^{\circ} \mathrm{C}$} \\
Cd & $\mathbf{2 5}$ & $\mathbf{3 5}$ & $\mathbf{4 5}$ \\
$\mathbf{C u}$ & 61.87 & 64.07 & 69.88 \\
& 18.86 & 20.43 & 22.03
\end{tabular}

\subsubsection{Thermodynamic parameters}

Thermodynamic parameters can be determined using the equilibrium constant $K$, which depends on temperature. The change in free energy $(\Delta G)$, enthalpy $(\Delta H)$ and entropy $(\Delta \mathrm{S})$ associated to the adsorption process were calculated by using following equations (Ramesh et al., 2005):

$$
\begin{gathered}
\Delta \mathrm{G}=\mathrm{RT} \ln \mathrm{K} \\
\ln \mathrm{K}=\frac{\Delta \mathrm{S}}{\mathrm{R}}-\frac{\Delta \mathrm{H}}{\mathrm{RT}} \\
\mathrm{K}=\frac{\mathrm{q}_{\mathrm{e}}}{\mathrm{C}_{\mathrm{e}}}
\end{gathered}
$$

Where $\mathrm{R}$ is the universal gas constant $\left(8.314 \mathrm{~J} \mathrm{~mol}^{-1} \mathrm{~K}^{-1}\right)$ and $\mathrm{T}$ is temperature $(\mathrm{K}), \mathrm{q}_{\mathrm{e}}\left(\mathrm{mg} \mathrm{g}^{-1}\right)$ and $\mathrm{C}_{\mathrm{e}}\left(\mathrm{mg} \mathrm{L}^{-1}\right)$ are the equilibrium concentration of pollutant adsorbed and remained in the solution, respectively. $\Delta H$ and $\Delta S$ parameters can be calculated from the slope and intercept of the plot of In $\mathrm{K}$ versus $1 / \mathrm{T}$ yields, respectively.
Thermodynamic parameters of the adsorption of metal ions onto Ghassoul clay are shown in Table 6. Gibbs free energy $(\Delta G)$ was calculated using InK values for different temperatures $\left(25,35\right.$ and $\left.45^{\circ} \mathrm{C}\right) . \Delta \mathrm{G}$, values obtained were all small and positive which suggests that the adsorption of $\mathrm{Cd}$ (II) and $\mathrm{Cu}$ (II) onto Ghassoul clay require some small amount of energy to convert reactants into products (Scheckel and Donald, 2001). On the other hand, the magnitude of $\Delta G$ increased with increasing the temperature indicated that a better adsorption is actually obtained at higher temperatures. The positive values of $\Delta \mathrm{H}$, (1.715 and $3.691 \mathrm{~kJ} \mathrm{~mol}^{-1}$ for $\mathrm{Cd}(\mathrm{II})$ and $\mathrm{Cu}(\mathrm{II})$ respectively), suggests that the adsorption reactions of $\mathrm{Cd}$ (II) and $\mathrm{Cu}$ (II) onto Ghassoul clay adsorbents are endothermic in nature meaning that increasing temperature will favour the adsorption of both metals. Endothermic adsorption of $\mathrm{Cd}$ (II) and $\mathrm{Cu}$ (II) ions has been observed by Bhattacharyya and Gupta, (2011) and Adebowale et al., (2008). Data of $\Delta S$ obtained for the adsorption of metal ions onto Ghassoul clay are shown in Table 6. It was found that adsorption of $\mathrm{Cd}$ (II) and $\mathrm{Cu}(\mathrm{II})$ has a negative $\Delta \mathrm{S}(-20,22$ and $-33,74$ $\mathrm{J} \mathrm{mol}^{-1}$ respectively). Other investigators were reported a value range of negative $\Delta S$ for the adsorption of heavy metals onto clays (Unuabonah et al., 2008, Gupta et al., 2004). The negative values obtained indicate a stable configuration of the metal ion on the Ghassoul clay adsorbent surface (Gupta and Bhattacharyya, 2006).

Table 6. Thermodynamic parameters for the adsorption of $\mathrm{Cd}(\mathrm{II})$ and $\mathrm{Cu}(\mathrm{II})$ onto Ghassoul clay at various temperatures

\begin{tabular}{cccccc}
\hline & $\boldsymbol{\Delta} \mathbf{H}\left(\mathrm{kJ} \mathrm{mol}^{-1}\right)$ & $\boldsymbol{\Delta S}\left(\mathrm{J} \mathrm{mol}^{-1}\right)$ & $\mathbf{\Delta G}_{\mathbf{2 9 8}}\left(\mathrm{kJ} \mathrm{mol}^{-1}\right)$ & $\boldsymbol{\Delta} \mathbf{G}_{\mathbf{3 0 8}}\left(\mathrm{kJ} \mathrm{mol}^{-1}\right)$ & $\boldsymbol{\Delta} \mathbf{G}_{318}\left(\mathrm{~kJ} \mathrm{~mol}^{-1}\right)$ \\
\hline $\mathbf{C u}$ & 3.691 & $-33,74$ & 13.746 & 14.084 & 14.421 \\
\hline $\mathbf{C d}$ & 1.715 & $-20,217$ & 7.740 & 7.942 & 8.144 \\
\hline
\end{tabular}

\section{Conclusion}

In the present work, Moroccan clay, without any previous activation treatment, has identified as a potentially attractive adsorbent for the treatment of metal ions in aqueous solutions. The empirical values of the adsorption showed that Langmuir and Freundlich isotherm models were more suitable for modeling the adsorption of heavy metals. It was in conformity with the existence of different 
types of possible adsorption sites on clay surface with considerable difference in energy. The adsorption capacity, determined with the Langmuir isotherm, was found as 86.34 and $15.41 \mathrm{mg} \mathrm{g}^{-1}$ for $\mathrm{Cd}(\mathrm{II})$ and $\mathrm{Cu}$ (II) respectively. Experimental kinetic data indicated that the pseudosecond-order model gives the good agreement between model fit and experimentally observed equilibrium adsorption capacity in addition to the large correlation coefficients. The high adsorption ability, wide $\mathrm{pH}$ range and thermodynamic stability of Ghassoul clay revealed that this Moroccan clay can be used as low-cost alternative adsorbents for removal of heavy metals in industrial wastewater.

\section{References}

Adebowale K.O., Unuabonah E.I. and Olu-Owolabi B.I. (2008), Kinetic and thermodynamic aspects of the adsorption of $\mathrm{Pb}^{2+}$ and $\mathrm{Cd}^{2+}$ ions on tripolyphosphate-modified kaolinite clay, Chemical Engineering Journal,136, 99-107.

Adebowale K.O., Unuabonah I.E. and Olu-Owolabi B.I. (2006), The effect of some operating variables on the adsorption of lead and cadmium ions on kaolinite clay, Journal of Hazardous Materials, B134, 130-139.

Al-Degs Y.S., El-Barghouthi M.I., Issa A.A., Khraisheh M.A. and Walker G.M. (2006), Sorption of $\mathrm{Zn}(\mathrm{II}), \mathrm{Pb}(\mathrm{II})$, and $\mathrm{Co}(\mathrm{II})$ using natural sorbents: equilibrium and kinetic studies, Water Research, 40, 2645-2658.

Alkan M. and Doagan M. (2001), Adsorption of Copper (II) Onto Perlite, Journal of Colloid and Interface Science, 243(2), 280291.

Bejjaoui R., Benhammou A., Nibou L., Tanouti B., Bonnet J.P., Yaacoubi, A. and Ammar A. (2010), Synthesis and characterization of cordierite ceramic from Moroccan stevensite and andalusite, Applied Clay Science, 49, 336-340.

Benhammou A. (2005), Valorisation de la stevensite du Jbel Rhassoul: application à l'adsorption des métaux lourds. PhD Thesis, Cadi Ayyad University, Marrakesh, Morocco.

Benhammou A., Tanouti B., Nibou L., Yaacoubi A. and Bonnet J.P. (2009), Mineralogical and physicochemical investigation of Mg-smectite from Jbel Ghassoul, Morocco, Clays and Clay Minerals, 57(2), 264-270.

Benhammou A., Yaacoubi A., Nibou L. and Tanouti B. (2005), Adsorption of metal ions onto Moroccan stevensite: kinetic and isotherm studies, Journal of Colloid Interface Science, 282, 320-326.

Bereket G., Aroguz A.Z. and Ozel M.Z. (1997), Removal of Pb(II), $\mathrm{Cd}(\mathrm{II}), \mathrm{Cu}(\mathrm{II})$, and $\mathrm{Zn}(\mathrm{II})$ from aqueous solutions by adsorption on bentonite, Journal of Colloid Interface Science, 187, 338343.

Bhattacharyya K.G. and Gupta S.S. (2011), Removal of Cu(II) by natural and acid-activated clays: An insight of adsorption isotherm, kinetic and thermodynamics, Desalination, 272, 6675.

Bosso S.T. and Enzweiler J. (2002), Evaluation of heavy metal removal from aqueous solution onto scolecite, Water Research, 36, 4795-4800.

Bouna L., Rhouta B., Amjoud M., Jada A., Maury F., Daoudi L. and Senocq F. (2010), Correlation between eletrokinetic mobility and ionic dyes adsorption of Moroccan stevensite, Applied Clay Science, 48(3), 527-530.
Bradbury M.H. and Bayens B. (1999), Modelling the sorption of Zn and $\mathrm{Ni}$ on Ca-montmorillonite, Geochimica et Cosmochimica Acta, 63, 325-336.

Chahi A., Duringer Ph., Ais M., Bouabdelli M., Guathier F. and Fritz B. (1999), Diagenetic transformation of dolomite into stevensite in lacustrine sediments from Jbel Rhassoul, Morocco, Sedimentary Research, 69, 1125-1135.

Chahi A., Fritz B., Duplay J., Weber F. and Lucas J. (1997), Textural transition and genetic relationship between precursor stevensite and sepiolite in lacustrine sediments (Jbel Rhassoul, Morocco), Clays Clay Minerals, 45(3), 378-389.

Chen H. and Wang A. (2007a), Kinetic and isothermal studies of lead ion adsorption onto palygorskite clay, Journal of Colloid and Interface Science, 307, 309-316.

Chen H., Zhao Y. and Wang A. (2007b), Removal of $\mathrm{Cu}$ (II) from aqueous solution by adsorption onto acid-activated palygorskite, Journal of Hazardous Materials, 149, 346-354.

Crini G. (2006), Non-conventional low-cost adsorbents for dye removal: a review, Bioresour. Technol., 97, 1061-1085.

Echeverria J.C., Zarranz I., Estella, J. and Garrido J.J. (2005), Simultaneous effect of $\mathrm{pH}$, temperature, ionic strength, and initial concentration on the retention of lead on illite, Applied Clay Science, 30, 103-115.

El Ass K., Laachach A., Alaoui A. and Azzi M. (2010), Removal of methylene blue from aqueous solution using Ghassoul, a lowcost adsorbent, Applied Ecology and Environmental Research, 8(2), 153-163.

El Ass K., Laachach A., Alaoui A. and Azzi M. (2011), Removal of methyl violet from aqueous solution using a stevensite-rich clay from Morocco, Applied Clay Science, 54, 90-96.

Faust G.T. and Murata K.J. (1953), Stevensite, redefined as a member of the montmorillonite group, American Mineralogist, 38, 973-987.

Fu F. and Wang Q., (2011), Removal of heavy metal ions from wastewaters: A review, Journal of Environmental Management, 92(3), 407-418.

Furusawa T. and Smith J.M. (1974), Intraparticle mass transport in slurries by dynamic adsorption studies, Journal of AlChe, 20(1), 88-93.

Gupta N., Prasad M., Singhal N. and Kumar V. (2009), Modeling the Adsorption Kinetics of Divalent Metal lons onto Pyrophyllite Using the Integral Method, Industrial and Engineering Chemistry Research, 48(4), 2125-2128.

Gupta S.S. and Bhattacharyya K.G. (2006), Adsorption of Ni(II) on clays, Journal of Colloid Interface Science, 295, 21-32.

Gupta V.K., Singh P. and Rahman N. (2004), Adsorption behaviour of $\mathrm{Hg}(\mathrm{II}), \mathrm{Pb}(\mathrm{II})$ and $\mathrm{Cd}(\mathrm{II})$ from aqueous solution on Duolite, C433: a synthetic resin, Journal of Colloid Interface Science, 275, 398-402.

Ho Y.S. (2006), Review of second-order models for adsorption systems, Journal of Hazardous Materials, 136, 681-689.

ljagbemi C.O., Baek M.H. and Kim D.S. (2009), Montmorillonite surface properties and sorption characteristics for heavy metal removal from aqueous solutions, Journal of Hazardous Materials, 166, 538-546.

Inghui Y. and Caoc Q. (2009), Biosorption of $\mathrm{Cd}^{2+}, \mathrm{Cu}^{2+}, \mathrm{Ni}^{2+}$ and $\mathrm{Zn}^{2+}$ ions from aqueous solutions by pretreated biomass of brown algae, Journal of Hazardous Materials, 163, 931-938.

Jiang M., Jin X., Lu X. and Chen Z. (2010), Adsorption of Pb(II), $\mathrm{Cd}(\mathrm{II}), \mathrm{Ni}(\mathrm{II})$ and $\mathrm{Cu}(\mathrm{II})$ onto natural kaolinite clay, Desalination,252, 33-39. 
Kraepiel A.M.L., Keller K. and Morel F.M.M. (1999), A model for metal adsorption on montmorillonite, Journal of Colloid Interface Science, 210, 43-54.

Lagergren S. (1898), About the theory of so-called adsorption of soluble substance, Kungliga Svenska Vetenskapsakademiens Handlingar, 24, 1-39.

Lai C.H., Chen C.Y., Wei B.L. and Yeh S.H. (2002), Cadmium adsorption on goethite-coated sand in the presence of humic acid, Water Research, 36, 4943-4950.

Langmuir I. (1918), Adsorption of gases on plain surfaces of glass mica platinum, Journal of the American Chemical Society, 40, 136-403.

Lazarević S., Janković-Častvan I., Jovanović D., Milonjić S., Janaćković Dj. and Petrović R. (2007), Adsorption of $\mathrm{Pb}^{2+}, \mathrm{Cd}^{2+}$ and $\mathrm{Sr}^{2+}$ ions onto natural and acid-activated sepiolites, Applied Clay Science, 37(1-2), 47-57.

Lv L., Hor M.P., Su F.B. and Zhao X.S. (2005), Competitive adsorption of $\mathrm{Pb}^{2+}, \mathrm{Cu}^{2+}$, and $\mathrm{Cd}^{2+}$ ions on microporous titanosilicate ETS-10, Journal of Colloid Interface Science, 287, 178-184.

Mathialagan T. and Viraraghavan T. (2002), Adsorption of cadmium from aqueous solutions by perlite, Journal of Hazardous Materials, 94, 291-303.

Nuhoglu Y. and Oguz E. (2003), Removal of copper (II) from aqueous solutions by biosorption on the cone biomass of Thuja orientalis, Process Biochemistry, 38, 1627-1631.

Ozdes D., Duran C. and Senturk H.B. (2011), Adsorptive removal of $\mathrm{Cd}(\mathrm{II})$ and $\mathrm{Pb}$ (II) ions from aqueous solutions by using Turkish illitic clay, Journal of Environmental Management, 92, 3082-3090.

Potgieter J.H., Potgieter-Vermaak S.S.a nd Kalibantonga P.D. (2006), Heavy metals removal from solution by palygorskite clay, Mineral Engineering, 19, 463-470.

Ramesh A., Lee D.J. and Wong J.W.C. (2005), Thermodynamic parameters for adsorption equilibrium of heavy metals and dyes from wastewater with low-cost adsorbents, Journal of Colloid and Interface Science, 291, 588-592.

Sari A., Tuzen M., Soylak M. and Citak D. (2007), Equilibrium, kinetic and thermodynamic studies of adsorption of $\mathrm{Pb}(\mathrm{II})$ from aqueous solution onto Turkish kaolinite clay, Journal of Hazardous Materials, 149, 283-291.

Scheckel K.R. and Donald L. (2001), Sparks temperature effects on nickel sorption kinetics at the mineral-water interface, Soil Science Society America Journal, 65, 719-728.

Sdiri A., Higashi T., Hatta T., Jamoussi F. and Tase N. (2011), Evaluating the adsorptive capacity of montmorillonitic and calcareous clays onthe removal of several heavy metals in aqueous systems, Chemical Engineering Journal, 172, 37- 46.

Stathi P., Litina K., Gournis D., Giannopoulos T.S. and Deligiannakis Y. (2007), Physicochemical study of novel organoclays as heavy metal ion adsorbents for environmental remediation, Journal of Colloid and Interface Science, 316(2), 298-309.

Stumm W. (1997), Reactivity at the mineral-water interface: dissolution and inhibition, Colloids and Surfaces $A$ : Physicochemical and Engineering Aspects, 120, 143-66.

Takahashi N., Tanaka M., Satoh T., Endo T. and Shimada M. (1997), Study of synthetic clay minerals. Part IV: synthesis of microcrystalline stevensite from hydromagnesite and sodium silicate, Microporous Materials, 9(1-2), 35-42.

Unuabonah E.I., Adebowale K.O., Olu-Owolabi B.I., Yang L.Z. and Kong L.X. (2008), Adsorption of $\mathrm{Pb}$ (II) and $\mathrm{Cd}$ (II) from aqueous solutions onto sodium tetraborate-modified kaolinite clay: equilibrium and thermodynamic studies, Hydrometallurgy, 93, 1-9.

Weber W.J. and Morris J.C. (1963), Kinetics of adsorption on carbon from solution, Journal of the Sanitary Engineering Division, 89, 31-60.

Yang C.H. (1998), Statistical mechanical study on the Freundlich isotherm equation, Journal of Colloid Interface Science, 208, 379-387. 